\title{
Rancang Bangun Alat Pengupas Kulit Singkong Dengan Prinsip Mesin Bubut
}

\author{
Hesty Fanila ${ }^{1}$ Marhadi Sastra ${ }^{2}$ \\ 1) Program Studi Teknik Mesin, Politeknik Negeri Bengkalis \\ 2) Program Studi Teknik Sipil, Politeknik Negeri Bengkalis \\ Jl. Bathin Alam, Sungai Alam, Bengkalis \\ Email: hestyfanila@polbeng.ac.id
}

\begin{abstract}
ABSTRAK
Singkong merupakan salah satu potensi lokal Indonesia melimpah dan belum termanfaatkan secara optimal. Singkong dapat diolah menjadi berbagai bahan pangan, salah satu panganan yang praktis dari hasil olahan singkong adalah keripik. Kendala yang sering dirasakan produsen keripik adalah proses pengupasan yang biasanya dilakukan secara manual yang membutuhkan waktu yang lama. Untuk mendukung proses produksi keripik, dibutuhkan tenaga kerja yang banyak. Metode pengupasan manual dilakukan dengan cara menyayat kulit singkong secara memanjang kemudian mencongkel kulit secara memutar. Pada kondisi ini, pekerja pada kondisi yang tidak aman karena memungkinkan tersayatnya tangan pekerja oleh pisau. Berdasarkan kondisi dan situasi tersebut mendorong penciptaan teknologi pengupasan singkong yang efisien dan aman berupa alat pengupas singkong berpenggerak motor listrik dengan menggunakan prinsip dasar mesin bubut.
\end{abstract}

Kata kunci: Alat pengupas, Kulit singkong, Mesin bubut

\begin{abstract}
Cassava is one of the local potential of Indonesia is abundant and has not been utilized optimally. Cassava can be processed into a variety foods, one snacks practical results are processing cassava chips. Obstacles often felt by manufacturers of chips is peel process that is usually done manually which takes a long time. To support the production process chips, it takes a lot of employee. Method of manual peel is done by slicing cassava peel lengthwise and then prying skin plays. In this condition, the worker is in an unsafe condition because it allows the hand to be slashed by the knife. Based on the conditions and the situation peel cassava encourage the construct of
\end{abstract}


technology that is efficient and safe form of motorized cassava peeler electricity by using the basic principle of the lathe.

Keywords: Peeler, Cassava skin, Lathe

\section{Pendahuluan}

Proses produksi keripik singkong didahului dengan proses pengupasan kulit singkong. Proses pengupasan kulit singkong biasanya dilakukan secara manual. Proses pengupasan manual ini membutuhkan waktu yang lama sehingga untuk mendukung proses produksi singkong dibutuhkan tenaga kerja yang banyak pada proses pengupasan. Metode pengupasan manual dilakukan dengan cara menyayat kulit singkong secara memanjang (sejajar dengan sumbu singkong) kemudian mencongkel kulit secara memutar. Metode ini menempatkan pekerja pada kondisi yang tidak aman karena memungkinkan tersayatnya tangan pekerja oleh pisau. Situasi dan kondisi tersebut mendorong penciptaan teknologi pengupasan singkong yang efisien dan aman, yaitu dengan merancang alat pengupas singkong dengan penggerak motor listrik dengan menggunakan prinsip dasar mesin bubut.

Penelitian tentang rancangan alat pengupas kulit pada umbi-umbian seperti singkong, talas dan kentang sudah banyak dilakukan dengan berbagai metode yang dipakai. Beberapa penelitian yang telah dilakukan untuk rancangan alat pengupas kulit umbi-umbian yaitu rancang bangun prototype alat pengupas kulit singkong berpenggerak motor listrik yang diteliti oleh Agung Setiawan Syahputra Chaniago (2015). Penelitian ini membahas tentang desain prototype untuk memilih, membentuk dan merangkai komponen-komponen dengan menggunakan prinsip mekanisme pengupasan menggunakan model pengupasan rotasi, pengupasan bertipe serabut dengan kekakuan tertentu dan pengumpanan bahan singkong dilakukan secara manual dan satu persatu. Hasil dari penelitian ini setelah perancangan alat yaitu dalam proses pengupasan tidak sampai keseluruhan bagian singkong dapat terkelupas karena terdapat bagian yang tidak dapat dijangkau oleh sikat pengupas. Untuk diameter singkong terbatas pada ukuran $4 \mathrm{~cm}-5 \mathrm{~cm}$ disebabkan karena jangkauan sikat pengupas yang masih terbatas.

Penelitian lain yang menjadi rujukan adalah beberapa penelitian tentang mesin bubut. Salah satu penelitian yang menjadi rujukan pada penelitian ini adalah pengaruh variasi kecepatan putaran mesin bubut terhadap keausan pada alat potong pahat HSS tipe Bohler MO1/2X4 (Dewangga, Nugraha, \& Dantes, 2017) tentang pengaruh variasi kecepatan pada pembubutan specimen besi, aluminium, dan kayu.

UNITEX Vol 11 No.2 Juli - Desember 2018 | p-ISSN 2089-3957 | e-ISSN 2580-2585 
Dari beberapa penelitian yang telah dilakukan, didapat suatu ide dari peneliti untuk mengmbangkan suatu penelitian tentang rancang bangun alat pengupas kulit singkong dengan prinsip mesin bubut.

\section{Metode Penelitian}

Penelitian ini diawali dengan identifikasi dan perumusan masalah, studi literature dari beberapa penelitian yang telah dilakukan sebelumnya, membuat rancangan dan desain, melakukan pembuatan dan perancangan alat pengupas singkong dengan menggunakan prinsip mesin bubut, dan kemudian dilakukan pengujian, pengambilan data dan terakhir mengambil kesimpulan. Secara garis besar, tahapan penelitian dapat digambarkan pada diagram alir penelitian sebagai berikut:

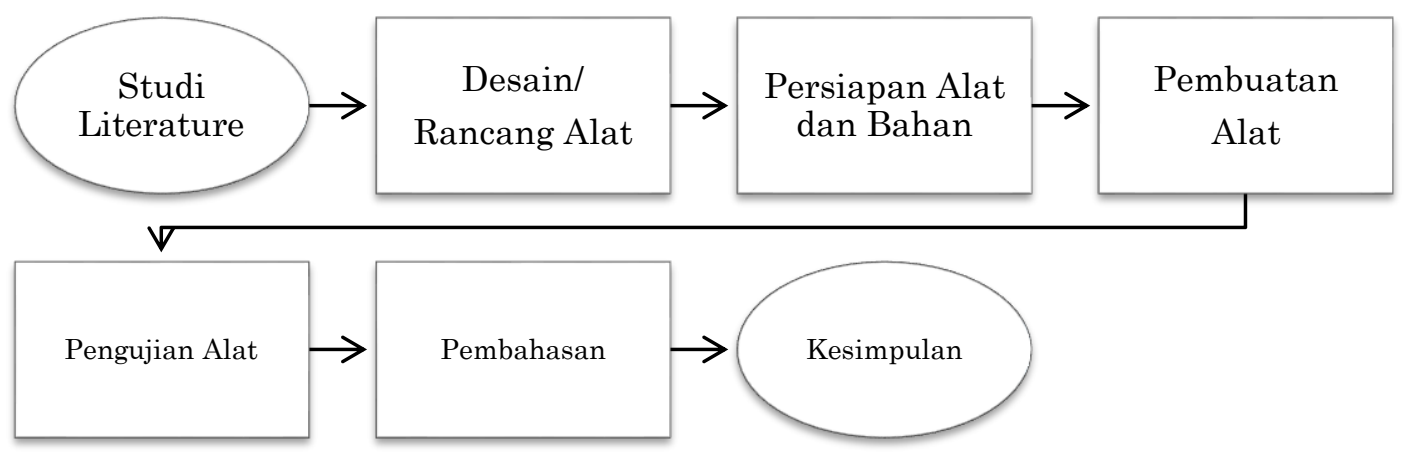

Gambar 1. Diagram Alir Penelitian

Adapun berdasarkan diagram alir penelitian, tujuan penelitian adalah untuk merancang alat pengupas kulit singkong. Proses Pembuatan atau rancang bangun alat pengupas kulit singkong ini dimulai dari desain awal dan gambar, yang dilanjutkan dengan pekerjaan dan pengujian. Setelah pembuatan alat mesin pengupas kulit singkong dilakukan proses pengujian alat. Dalam pengujian dipersiapkan terlebih dahulu singkong untuk mengetes peralatan yang telah dirancang. 


\section{Hasil dan Pembahasan}

\section{Desain Alat Pengupas Singkong}

Penelitian ini diawali dengan merancang dan membuat desain dari alat yang akan dibuat. Rancangan dan desain awalnya dibuat secara manual dan setelahnya dibuat dengan menggunakan aplikasi komputer. Aplikasi yang digunakan yaitu CAD/CAM. Dimensi dan ukuran yang akan dibuat untuk alat pengupas singkong dengan prinsip mesin bubut akan disesuaikan dengan ukuran secara umum dari singkong. Dalam penelitian ini ukuran dari alat yang akan dibuat adalah panjang $100 \mathrm{~cm}$, tinggi $34 \mathrm{~cm}$, dan lebar $20 \mathrm{~cm}$.

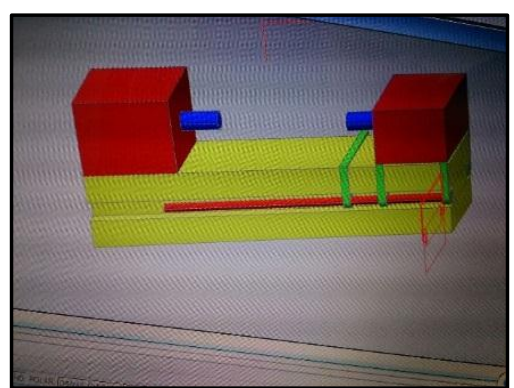

Gambar 2. Desain alat pengupas singkong

Rancangan pada gambar merupakan suatu tuntunan atau pedoman dalam membuat alat pengupas singkong dengan prinsip dasar mesin bubut. Setelah dilakukan proses desain, selanjutnya dengan menggunakan beberapa peralatan, proses pabrikasi dapat dilakukan sampai alat tersebut siap dirakit.

\section{Pembuatan Alat Pengupas Singkong Dengan Prinsip Dasar Mesin Bubut}

Dengan menggunakan desain alat pada gambar 2, maka akan dilakukan pembuatan alat pengupas singkong dengan prinsip dasar mesin bubut. Karena menggunakan prinsip dasar mesin bubut, maka bentuk dari alat ini akan menyerupai mesin bubut konvensional. Tetapi dalam penelitian ini, akan dibuat lebih kecil disesuaikan dengan ukuran singkong pada umumnya.

Bahan yang digunakan untuk merancang Alat Pengupas Singkong dengan Prinsip Dasar Mesin Bubut adalah besi siku dan Besi U, serta Pelat Stainlees steel. Besi siku dan besi U dirangkai dan selanjutnya dilapisi dengan menggunakan pelat Stainless steel. Plat Stainlees steel terbuat dari campuran beberapa bahan dasar seperti mangan, silicon, nikel, kromium dan karbon. Ada banyak keunggulan yang bisa diperoleh dari peralatan stainless steel. Umumnya, keunggulan stainless steel terletak pada jangka penggunaan yang lebih tahan lama, mudah dibersihkan, sangat kuat dan anti karat. 


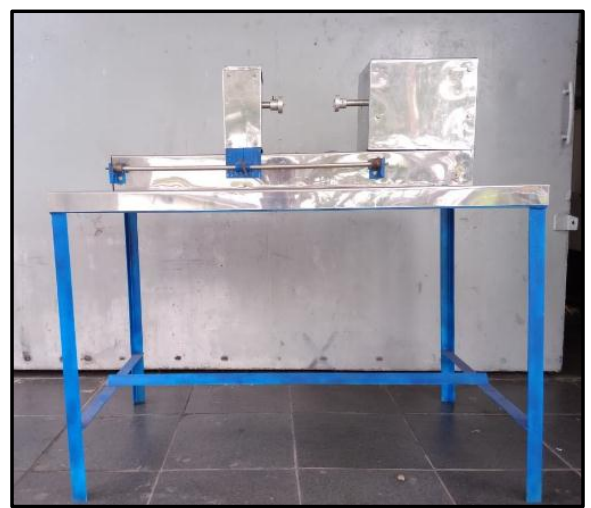

Gambar 3. Alat pengupas kulit singkong dengan prinsip mesin bubut

Dari Gambar 3 dapat dilihat hasil akhir dari rancang bangun alat pengupas kulit singkong dengan prinsip dasar mesin bubut bahwa alat yang dihasilkan dibuat menyerupai mesin bubut konvensional. Akan tetapi, untuk dimensi dan alat yang digunakan disesuaikan dengan kondisi dan spesifikasi dari bahan benda kerja yang pada penelitian ini merupakan singkong.

Alat pencekam benda kerja yang biasa dipakai adalah cekam (Chuck). Chuck adalah salah satu alat perlengkapan mesin bubut yang fungsinya untuk menjepit atau mengikat benda kerja pada proses pembubutan. Pembuatan Chuck untuk alat pengupas singkong ini disesuaikan dengan spesifikasi bahan yang akan dicekam. Singkong memiliki tekstur daging yang keras namun mudah patah dan pecah. Dengan demikian, chuck didesain sesuai dengan spesifikasi singkong. Mata pisau yang digunakan untuk singkong ini harus tajam dan mengikuti bentuk dari singkong yang berbentuk bulat lonjong.

\section{Hasil Uji Alat}

Setelah melakukan serangkaian proses dalam pembuatan alat pengupas singkong dengan prinsip dasar mesin bubut, maka untuk melihat layak atau tidaknya alat tersebut akan dilakukan pengujian alat. Berikut beberapa pengujian yang dilakukan untuk alat pengupas kulit singkong dengan prinsip dasar mesin bubut. 
Tabel 1. Data kecepatan dan diameter singkong

\begin{tabular}{|c|c|r|}
\hline No & $\begin{array}{c}\text { Kecepatan } \\
\text { putaran (rpm) }\end{array}$ & $\begin{array}{c}\text { Diameter } \\
(\mathrm{mm})\end{array}$ \\
\hline 1 & 322 & 70 \\
\hline 2 & 526 & 50 \\
\hline 3 & 412 & 50 \\
\hline 4 & 200 & 45 \\
\hline 5 & 288 & 50 \\
\hline 6 & 203 & 60 \\
\hline 7 & 196 & 50 \\
\hline 8 & 245 & 40 \\
\hline 9 & 623 & 40 \\
\hline 10 & 194 & 50,6 \\
\hline Rata-rata & 320,9 & \\
\hline
\end{tabular}

Berdasarkan dari Tabel 1, dapat ditentukan kecepatan potong rata-rata untuk alat pengupas kulit singkong sebagai berikut :

$$
\begin{aligned}
& V=\frac{\pi \cdot d \cdot n}{1000} \\
& V=\frac{3,14 \times 50,6 \times 320,9}{1000} \\
& V=50,98 \mathrm{~mm} / \text { menit } \\
& V=51 \mathrm{~mm} / \text { menit }
\end{aligned}
$$

Pada dasarnya, umbi singkong terdiri atas tiga lapisan yang meliputi:

a. Lapisan kulit luar, Merupakan lapisan kulit yang tipis; yang mudah robek, berwarna coklat, dan coklat abu-abu.

b. Lapisan kulit dalam, Merupakan suatu lapisan kulit yang memiliki ketebalan antara $1 \mathrm{~mm}-3 \mathrm{~mm}$; warna kuning dan berwarna putih.

c. Daging : bagian yang memiliki persentasi terbesar dari singkong yang berbentuk bulat panjang. Panjang singkong bervariasi antara $10 \mathrm{~cm}$ sampai dengan $35 \mathrm{~cm}$. 
Untuk melihat hasil dari pengupasan singkong, dapat ditentukan dengan melihat hasil pengupasan yang dapat dilihat dari beberapa sampel. Sampel pertama pada Gambar 4.

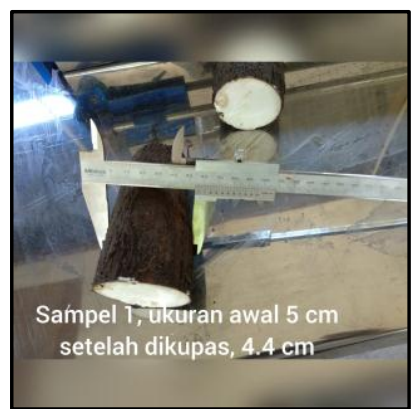

Gambar 4. Hasil pengupasan kulit singkong sampel 1

Untuk menghitung kedalaman potong pada sampel pertama, dapat menggunakan persamaan:

$$
\begin{aligned}
& a=\left(\frac{d_{0}-d_{m}}{2}\right) \\
& a=\left(\frac{5-4,4}{2}\right) \\
& a=0,3 \mathrm{~cm}=3 \mathrm{~mm}
\end{aligned}
$$

Berdasarkan karakteristik dari singkong yang terdiri dari tiga lapisan kulit yaitu kulit luar yang berwarna kecoklatan, lapisan kulit dalam yang berkisar antara 1-3 mm, dan daging singkong yang memiliki persentasi paling besar. Dari hasil perhitungan kedalaman potong dari singkong pada sampel pertama dapat kita jelaskan bahwa singkong terkupas secara sempurna dengan kedalaman $3 \mathrm{~mm}$. Artinya, alat pengupas kulit singkong bekerja sempurna pada sampel satu. Untuk sampel kedua, dapat dilihat dari Gambar 5. 

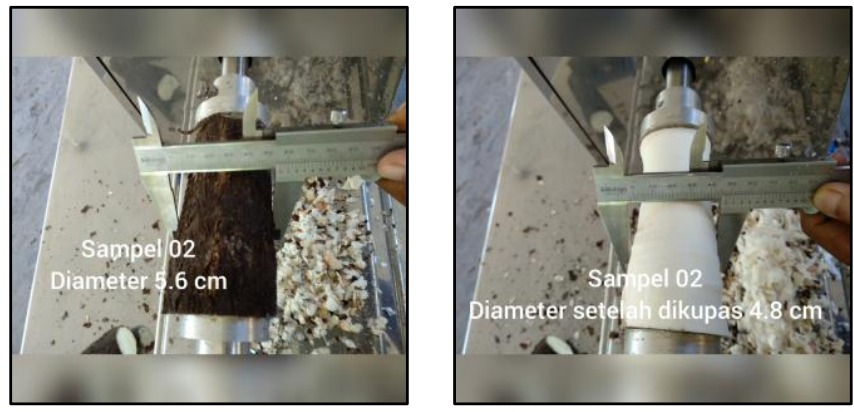

Gambar 5. Hasil pengupasan kulit singkong sampel 2

Untuk menghitung kedalaman potong pada sampel kedua, dapat menggunakan persamaan:

$$
\begin{aligned}
& a=\left(\frac{d_{0}-d_{m}}{2}\right) \\
& a=\left(\frac{5,6-4,8}{2}\right) \\
& a=0,4 \mathrm{~cm}=4 \mathrm{~mm}
\end{aligned}
$$

Berdasarkan perhitungan dari kedalaman potong pada sampel kedua, didapat hasil perhitungan sebesar $4 \mathrm{~mm}$. Artinya, kedalaman potong pada sampel kedua lebih dalam $1 \mathrm{~mm}$. Hal ini terjadi kemungkinan karena kedalaman pada mata pisau pada saat pemakanan potong. Untuk sampel ketiga dapat dilihat pada Gambar 6 . 

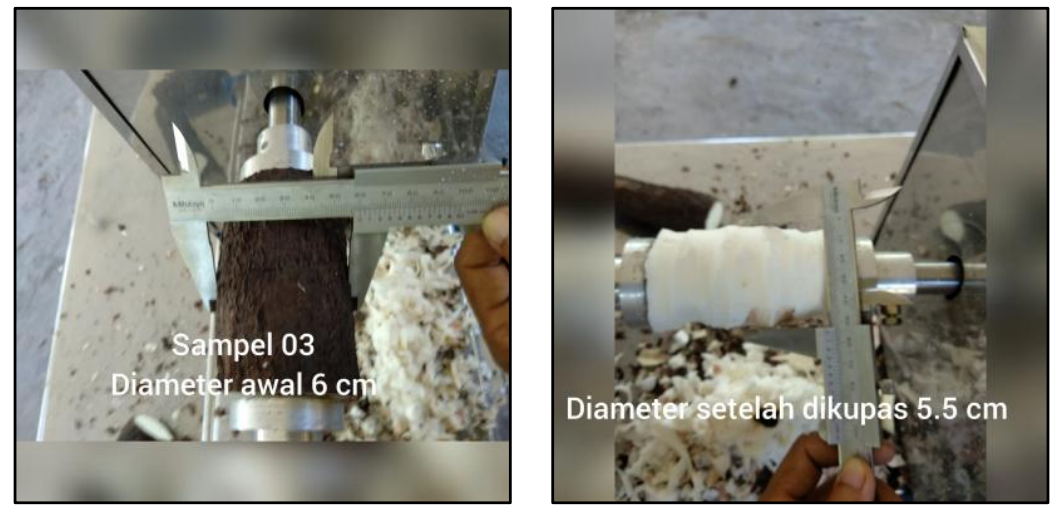

Gambar 6. Hasil pengupasan kulit singkong sampel ketiga

Untuk menghitung kedalaman potong pada sampel ketiga, dapat menggunakan persamaan:

$$
\begin{aligned}
& a=\left(\frac{d_{0}-d_{m}}{2}\right) \\
& a=\left(\frac{6-5,5}{2}\right) \\
& a=0,25 \mathrm{~cm}=2,5 \mathrm{~mm}
\end{aligned}
$$

Dari hasil perhitungan kedalaman potong dari singkong pada sampel ketiga dapat dijelaskan bahwa singkong terkupas secara sempurna dengan kedalaman 2,5 mm. Artinya, alat pengupas kulit singkong bekerja sempurna pada sampel ketiga.

\section{Simpulan}

Berdasarkan penelitian tentang rancang bangun alat pengupas kulit singkong dengan prinsip dasar mesin bubut dapat disimpulkan bahwa alat yang dirancang dan dibangun dimensinya adalah $100 \times 20 \times 34 \mathrm{~cm}$, yang disesuaikan dengan kebutuhan akan objek kerja yang dipakai berupa singkong. Untuk hasil pengujian alat cukup baik, dapat dilihat dari kedalaman potong dari beberapa sampel yaitu tidak jauh dari 1-3 mm.

UNITEX Vol 11 No.2 Juli - Desember 2018 | p-ISSN 2089-3957 | e-ISSN 2580-2585 


\section{Ucapan Terima Kasih}

Penulis mengucapkan terima kasih kepada Direktorat Pendidikan Tinggi, yang telah memberikan dukungan finansial melalui Hibah Penelitian Dosen Pemula.

\section{Daftar Pustaka}

Amin, S. (1989). Dasar-dasar Perkakas dan Mesin Perkakas. Jakarta: CV. Rajawali.

Chaniago, A. S. (2015). Rancang Bangun Prototipe Alat Pengupas Kulit Singkong Berpenggerak Motor Listrik. Semarang: Universitas Diponegoro.

Dewangga, S. F., Nugraha, P., \& Dantes, K. R. (2017). Pengaruh Variasi Kecepatan Putaran Mesin Bubut Terhadap Keausan pada Alat Potong Pahat HSS Tipe Bohler MO 1/2X4. Jurnal Jurusan Pendidikan Teknik Mesin, Vol:7 No:1, 1-10.

Hamdhani, F., \& Hamsi, A. (2014). Optimasi Pemesinan Pada Mesin Bubut Tipe M300 Horrison dengan Metode Optimasi Algoritma Genetika. Jurnal e-Dinamis, Vol:8, No:4, 1-10.

Kurniawan, F. (2008). Study Tentang Cutting Force Mesin Bubut (Desain Dynamometer Sederhana). Surakarta: Universitas Muhammadiyah Surakarta.

Nawawi, I. R. (-). Perencanaan dan Pembuatan Mesin Bubut Kayu dalam Mempercepat Proses Produksi. Ponorogo: Universitas Muhammadiyah Ponorogo.

Permana, F. Y., \& Rameli, M. (2012). Pengaturan Kecepatan Spindle pada Retrofit Mesin Bubut CNC Menggunakan Kontroler PI Gain Scheduling. Jurnal Teknik Pomits Vol.1 No.1, 1-5.

Rahdiyanta, D. (2010). Proses Bubut (Turning). Yogyakarta: Universitas Negeri Yogyakarta.

Statistik, B. P. (2013). Data Sensus Produksi Ubi Kayu Menurut Provinsi (Ton). Indonesia: BPS.

Syamsudin, R. (2000). Teknik Bubut. Jakarta: Puspa Swara.

UNITEX Vol 11 No.2 Juli - Desember 2018 | p-ISSN 2089-3957 | e-ISSN 2580-2585 